Military Technical College

Kobry El-Kobbah,

Cairo, Egypt

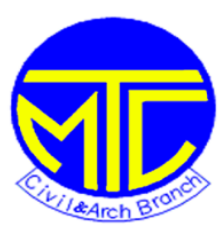

$12^{\text {th }}$ International Conference

on Civil and Architecture

Engineering

ICCAE-12-2018

\title{
Building a framework for urban low-carbon governance system of Smart City
}

\author{
Taher Osman ${ }^{1,2,3}$ \\ ${ }^{1}$ Assistant Professor, Faculty of Urban and Regional Planning, Cairo University, Egypt. \\ ${ }^{2}$ Assistant Professor (Adjunct), Environmental Engineering Program, Zewail City of Science and Technology, Egypt. \\ ${ }^{3}$ Visiting Researcher, Department of Urban design, Planning, and Disaster management, Kyushu University, Japan. \\ Email:taher@kyudai.jp, taher.mohamed2009@cu.edu.eg
}

Recently in developing countries,discussions of urban low-carbon information governance have long been focused on aspects of system, strategy, urban form and culture at a macro-level, and limited to aspects relating specific energy-saving techniques at a micro-level. As the basis to achieve carbon reduction targets, data processing and calculation of carbon emissions with advanced technology is still lagging, especially the lack of data from end-users. Therefore, both the construction and the implementation of urban low-carbon information governance system have proven difficult. Through a combination of international research and experience, this paper proposes an approach to building the urban low-carbon information governance system based on smart techniques with the performance of end-users. Relying on three aspects of carbon regulatory mechanisms, the dynamic and static carbon regulatory model and the urban low-carbon information regulatory platform, this paper specifically addressed: 1 . the realization to monitor atmospheric $\mathrm{CO} 2$ concentration, distribution and trends. 2. The process of information collection, transmission, decision-making and feedback. 3. The system's implementation path including carbon emissions governance, energy governance, traffic governance, and building governance. The system facilitates the implementation of urban lowcarbon governance and provides a new way for re-thinking the combination of Low-carbon City and Smart City.

Keywords: Smart City; Smart Technique; Developing countries;Low-Carbon Information Governance; Governance System; Implementation path

\section{Introduction}

At present, developing countriesare in a rapid urbanization period.Urbanization has brought about enormous wealth, butat the same time, carbon emission has not be wellcontrolled as the existence of some unreasonablefactors. In response to climate change, it is a globalconsensus to build up low-carbon cities(Osman et al., 2016). At theUnited Nations Climate Change Conference held inCopenhagen, Denmark, 2009, developing countries have made 
thecommitment that by 2020 carbon dioxide emissionsper unit of GDP will decrease by $40 \%$ $45 \%$ thanthat of in 2005 (Osman et al., 2016). Thus the task of energy saving andlow-carbon governance system construction becomesmore urgent.As an important part in urban lowcarbonconstruction, low-carbon information governance isthe full guarantee not only for the realization inreducing carbon emissions qualitatively andquantitatively, but also for building an efficient andhealthy living environment (Osman et al., 2016, BaoxingQIU, 2009).Moreover, it is the objective requirement for urbansustainable development. However, currentresearches on construction of low-carbon informationgovernance system have focused on the macro level,relating the innovation of regulatory mechanisms andinstitutions (Rongtao DING, 2011; Zhilin LIU, 2013).

And at the micro level, limited by regulatorytechnology, some tasks such as data processing andcalculation of greenhouse gas emissions, which is thefoundation of reducing carbon emission, is still lagging, especially the lack of data from end users. Itaffects the implementation of low-carbon informationgovernance system to some extent. In addition, at theregulatory level, there is a lack of feedback from theregulated to the regulator. Previous research hasemphasized more on unidirectional management thanthe interactive relationship between government, enterprise, research institution and the public(Osman et al., 2016). Allthese above were insufficient to support theformulation of policies to reduce emissions and theproposal of planning methods. Thus, throughanalyzing a series of international researches andexperience, three ideas are proposed in this paper: Anintegrative approach to building urban lowcarboninformation governance system with smarttechniques, the building principles, and theimplement path of the system. The proposed systemis able to achieve the target by integratingmacroeconomic policy and micro smart technology toimprove the low-carbon city construction.

\section{Smart City and International UrbanLow-Carbon Information Governance}

\subsection{Smart City}

Originated in IBM's "Smarter Planet", Smart City is afurther development of Digital City and InformationCity (Chaolin GU, 2011). It can process vast amountsof information, and propose decisions and feedbackin time through Cloud Computing, artificialintelligence technology and many other approaches.Manual work can be replaced by automation in theprocess of information-gathering anddecision-making. So, it is the key to solve problemssuch as resource shortage and environmentalpollution. The development of the Smart City isnecessarily 
conducive to promoting industrialupgrading, the mode of production, and lifestylechanging in energy saving. Smart City is anunstoppable development trend of future city (XiboWU, Zaigao YANG, 2010; Sidong ZHAO, etc.2013). The difference between the Smart City and theDigital City is that, the Smart City changes the waythat government, enterprise and the public interactwith each other. With the help of advancedtechnology and intelligent methods like sensors, theinternet of things, cloud computing and the newgeneration of information technology, everyparticipation is capable of obtaining decisions andgiving feedback. In one sentence, "Smart City =Digital City + the Internet of Things+ CloudComputing Technology" (Sidong ZHAO, etc., 2013).Nowadays, many cities in developing countries have constructed plans ofSmart Cities. For example, in China, Beijing, Shanghai, Guangzhou, Shenzhen,Hangzhou, Nanjing, Ningbo, Wuhan, Xiamen andShuangliu have developed special plans for smart cityconstruction (Xinbo WU, Zaigao YANG, 2010).

\subsection{International Smart Urban Low-CarbonInformation Governance}

After its emerging, the Smart City concept raisedextensive concerns all over the world. Thus, there aresome researches and construction experiences in thearea of intelligent low-carbon governance. InStockholm, the construction of smart traffic systemhas reduced the greenhouse gas emissions. Motorvehicle flow had be controlled by introducing roadcongestion charge system. In response to the changeof road congestion time as the traffic flow decreased,local department of transportation had to re-designthe public transport timetables at the end of the testperiod. Another example is Boulder, which is the firstsmart power grid city in American. Throughupgrading traditional grid, using remote monitoringstations and automated smart meters, it achieved thetarget of reducing energy consumption and carbonemission. Taipei has explored smart building in thedetails with wireless sensor networks. Ireland gotremarkable result in the construction of smartenvironment governance. IBM built "Smart Bay" onthe west coast in cooperation with the localenvironmental protection agency. By collecting andanalyzing large amounts of data about water quality,tides, weather forecasting and other environmentalinformation, peopleand the power plants are able to make their arrangement more reasonable (Table 1).

In addition to those above, the real-timegovernance of atmospheric $\mathrm{CO} 2$ concentration is thefundamental guarantee of carbon emission reduction(Osman et al., 2016).With further research on application of remotesensing data and analysis on data observed by carbonsatellites, it is possible to monitor atmospheric CO2concentration using satellite remote 
sensingtechnology, and it can also provide first-hand data forintelligent low-carbon governance (Qi LI, etc., 2014).In this aspect, early practice has been carried out byJapan. Japan's greenhouse gases observing satellite (GOSAT) launched successfully in January 2009, andit is able to monitor atmospheric $\mathrm{CO} 2$ concentrationsin the certain part of the region. In the future, theUnited States, China and Germany all have plans tolaunch carbon satellites to provide decision supportand set up policy for the carbon governance of SmartCity (Table 2).

It can be summarized from all researches above,the intelligent low-carbon information governancesystem should include four aspects: 1) smart carbonemission governance 2) smart energy governance 3)smart traffic governance 4) smart buildinggovernance. All these management means arenecessary to reduce carbon emissions, and play animportant role in improving the effectiveness oflow-carbon city construction.

Table 1 The famous cases of smart low carbon governance system

\begin{tabular}{|c|c|c|c|c|}
\hline & $\begin{array}{l}\text { Content of } \\
\text { governance }\end{array}$ & $\begin{array}{l}\text { Main } \\
\text { participant }\end{array}$ & Information platform & $\begin{array}{l}\text { Outstanding } \\
\text { achievement }\end{array}$ \\
\hline Stockholm & Smart trafficgovernance & $\begin{array}{l}\text { Government } \\
\text { enterprisethe } \\
\text { public }\end{array}$ & $\begin{array}{l}\text { Information collection } \\
\text { system, } \\
\text { informationmanagement } \\
\text { and release platform }\end{array}$ & $\begin{array}{l}\text { Traffic congestion reduced } \\
25 \% \text {, queuing time } \\
\text { dropped } 50 \% \text {, greenhouse } \\
\text { gasemissions fell } 40 \% \text {; } \\
\text { won the first "European } \\
\text { Green Capital" title }\end{array}$ \\
\hline Boulder & $\begin{array}{l}\text { Smart energy } \\
\text { governance }\end{array}$ & $\begin{array}{l}\text { Government } \\
\text { enterprisethe } \\
\text { public }\end{array}$ & $\begin{array}{l}\text { Information sensing } \\
\text { system, information } \\
\text { processing platform }\end{array}$ & $\begin{array}{l}\text { Each family saved } 25 \% \text { of } \\
\text { electricity, reduced } \\
\text { fuelconsumption and } \\
\text { carbon emissions }\end{array}$ \\
\hline Taipei & $\begin{array}{l}\text { Smart building } \\
\text { governance }\end{array}$ & $\begin{array}{l}\text { Enterprise the } \\
\text { public }\end{array}$ & $\begin{array}{l}\text { Information collection } \\
\text { system, } \\
\text { informationmanagement } \\
\text { platform, response } \\
\text { system }\end{array}$ & $\begin{array}{l}\text { Realized smart lighting } \\
\text { and ventilation regulation, } \\
\text { reduced } 20 \% \text { of the annual } \\
\text { electricity consumption } \\
\text { and carbonemissions }\end{array}$ \\
\hline Ireland & $\begin{array}{l}\text { Smart } \\
\text { environmentgovernance }\end{array}$ & $\begin{array}{l}\text { Government } \\
\text { enterprisethe } \\
\text { public }\end{array}$ & $\begin{array}{l}\text { Information collection } \\
\text { system, } \\
\text { informationmanagement } \\
\text { platform, media } \\
\text { responsesystem }\end{array}$ & $\begin{array}{l}\text { Fishermen have more } \\
\text { freedom to organizefishing } \\
\text { area; tidal power plants } \\
\text { can produce amore } \\
\text { reasonable arrangement }\end{array}$ \\
\hline
\end{tabular}


Table 2 Introduction of carbon satellites in different countries

\begin{tabular}{|c|c|c|c|c|}
\hline & Carbon satellite & Main purpose & Launch time & Condition \\
\hline Japan & $\begin{array}{l}\text { GOSAT (greenhouse } \\
\text { gases observing } \\
\text { satellite) }\end{array}$ & $\begin{array}{l}\text { To monitor the concentration of } \\
\mathrm{CO} 2 \text { in the atmosphere }\end{array}$ & $\begin{array}{l}\text { Launched in January } \\
2009\end{array}$ & Succeed \\
\hline \multirow[t]{2}{*}{ America } & $\begin{array}{l}\text { OCO (orbiting carbon } \\
\text { observatory) }\end{array}$ & $\begin{array}{l}\text { Study the source, sink and } \\
\text { transfer mode of } \mathrm{CO} 2 \text { in the } \\
\text { atmosphere }\end{array}$ & Launched in 2009 & Failed \\
\hline & OCO-2 & $\begin{array}{l}\text { Observation and supervision of } \\
\text { theglobal atmospheric } \mathrm{CO} 2 \mathrm{mix} \\
\text { ratio }\end{array}$ & $\begin{array}{l}\text { Expected to launch in } \\
2015\end{array}$ & $\begin{array}{l}\text { Wait for } \\
\text { launch }\end{array}$ \\
\hline China & TanSat & $\begin{array}{l}\text { To monitor the emissions in } \\
\text { Chinaand global greenhouse } \\
\text { gas }\end{array}$ & $\begin{array}{l}\text { Expected to launch in } \\
2015\end{array}$ & $\begin{array}{l}\text { Wait for } \\
\text { launch }\end{array}$ \\
\hline Germany & CarbonSat & $\begin{array}{l}\text { To monitor the level of } \mathrm{CO} 2 \\
\text { andmethane in the atmosphere }\end{array}$ & $\begin{array}{l}\text { Expected to launch in } \\
2018\end{array}$ & $\begin{array}{l}\text { Wait for } \\
\text { launch }\end{array}$ \\
\hline
\end{tabular}

3. Construction Principle of Urban Low-CarbonInformation Governance System in the Context ofSmart City

\subsection{Build a Highly Efficient and Integrated UrbanLow-Carbon Information Governance Platform}

Firstly, the city should build an urbanlow-carbon information governance platform, whichis the integration center organizing variousinformation resources including data of energynetwork, traffic, architecture and carbonemissions. Its central administration is a management andservices platform based on cloud computingtechnology, managing monitoring, coordination, command and feedback. This platform is built on theentire information governance network, and iscomposed of four subsystem platforms sharinginformation and a set of equipment for informationprocessing and transmission. This efficientinformation sharing model can avoid waste caused byrepeated statistics. For example, the householdelectricity consumption information collected in thesmart building system is re-collected in the smartenergy system, which can bring informationredundancy.

\subsection{Deepen the Reform of Low-Carbon RegulatoryMechanism Supported By Smart Techniques}


At present, from the overall perspective, thegovernment's unilateral management on lowcarboninformation governance exists some problems_-ineffective governance, single function and thelack of flexibility. Therefore, in Smart City, thetraditional sense of boundary between the regulatorand the regulated should be broken, and each groupmay become the regulators. Government departments,industries and enterprises, research institutions andthe public should share information, supervise eachother and participate in the whole process of urbanlow-carbon information governance.

\subsection{Develop the Dynamic and Static Low-CarbonRegulatory Model Based On Smart Techniques}

The dynamic and static is relative. The dynamicrefers to the real-time dynamic process, while thestatic refers to a process with relative cycle. Since thesmart technique itself is dynamic, people are able totimely acquire information on energy supply andconsumption, traffic flow and congestion, buildingenergy consumption, atmospheric $\mathrm{CO} 2$ concentrationand so on. However, not all of the real-time data canreflect issues, and restrictions on all real-time data arefar from complete. For example, the carbonemissions of a factory might fluctuate throughout theday. Thus, people should be concerned about the totalemissions over a period of time, but not just focus onits dynamic carbon emissions. Furthermore, byobserving and analyzing information on the carbonemissions during a period of time, people can find outright space structure of lowcarbon city, balance thecarbon sources and sinks, and provide decisions tosupport urban planning.

\section{Construction Method of Urban Low-CarbonInformation Governance System}

Under the smart city background, urban low-carboninformation governance system can be built throughtwo aspects: Building an intelligent low-carboninformation system and making the urban low-carboninformation governance system smarter (Fig. 1). On one hand, in the context of Smart City, it isnecessary to build intelligent information system forlow-carbon governance. The system is the action anddecision center of the entire intelligence system. Itconsists of three parts including an intelligentlow-carbon information governance platform, a smarttechnique support system and multi-regulatorymechanism. Firstly, the intelligent low-carboninformation governance platform is composed of aninformation collection system, an information sharingplatform, aninformation processing platform andinformation interactive terminals. Among them, inorder to deliver decisions and get feedback in time,information interactive terminals are 
tied up withgovernment regulation system, enterprise automationsystem, scientific research transformation system andpublic service system. Secondly, the smart technique support system is composed of a series of technologyincluding internet of things, cloud computing, mobileinternet, big data and spatial information. Lastly, themulti-regulatory mechanism consists of four mainbodies_-government departments, industries andenterprises, research institutions, and the public.Multi-regulatory governance is an important featurein the Smart City. And through an open andtransparent information management, everyone cancontribute suggestions for the governance. 


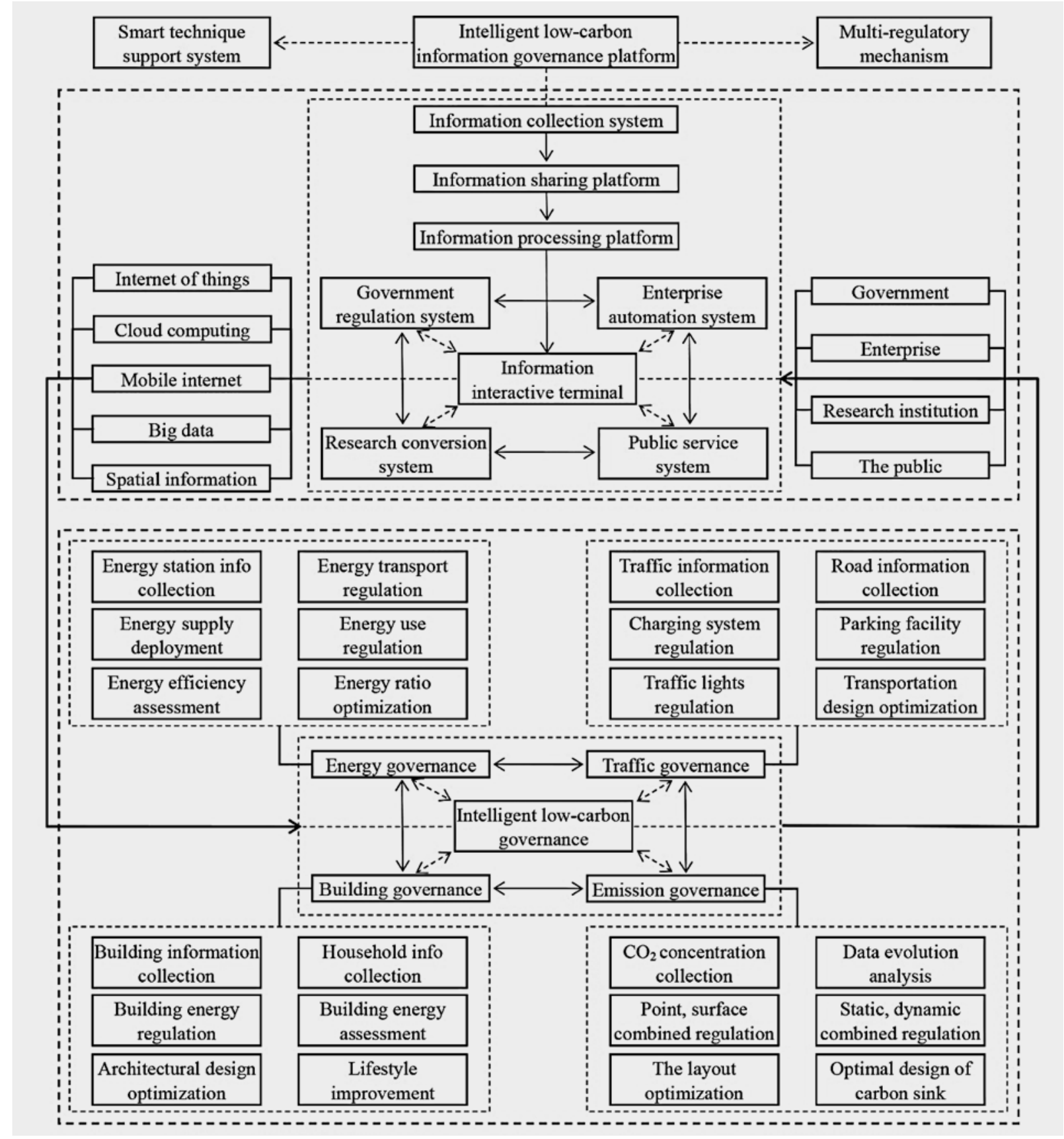

Fig. 1 The basic framework of urban low-carbon information governance system of Smart City

On the other hand, the intelligent informationsystem is applied to the four aspects of urbanlowcarbon information governance: carbon emissiongovernance, energy governance, traffic governanceand building governance. Those four aspects arecomplimentary and mutually beneficial to each other,and all together ensure the comprehensiveness andaccuracy of the governance. The advantages onmechanism, technology and platforms of this systemwill provide 
an efficient and safe support for thegovernance, thereby making the low-carbon citymore intelligent.

\section{Implementation Path of Intelligent Low-CarbonInformation Governance System According WithLow-Carbon City Construction}

The implementation path of urban low-carboninformation governance system is discussed fromfollowing four aspects: Smart carbon emissiongovernance, smart energy governance, smart trafficgovernance, and smart building governance.

\subsection{Smart Carbon Emission Governance}

In smart carbon emission governance, smarttechniques such as satellite remote sensing, GPS andGIS are demanded. Firstly, the carbon satelliteobtains information of $\mathrm{CO} 2$ absorption band and nearinfrared band, and calculates the average mixing ratioof $\mathrm{CO} 2$ column. Secondly, data listed above are sentto the intelligent carbon emission governanceplatform. In this step, the data are filtered andcorrected with inversion method and a series ofprecision rectification. Lastly, the data of CO2concentration in the monitoring area is obtained andthen shared on the information platform.

Table 3 Emission governance goals and issues

\begin{tabular}{|c|c|c|}
\hline \multicolumn{2}{|r|}{ Goal and task } & Main issues \\
\hline Goal: & $\begin{array}{l}\text { - Monitor and evaluate influence of human } \\
\text { activity on carbon balance. }\end{array}$ & 1) Lack of monitoring data of CO2 concentration. \\
\hline Task: & $\begin{array}{l}\text { 1) Monitor regional concentration of } \mathrm{CO} 2 \text {. } \\
\text { 2) Analysis contribution and impact of carbon } \\
\text { source and sink. } \\
\text { 3) Monitor carbon emissions. } \\
\text { 4) Guide the planning and construction of low- } \\
\text { carbon city. }\end{array}$ & $\begin{array}{l}\text { carbon cycle. } \\
\text { 3) Lack of supporting data of carbon balance in } \\
\text { planning. } \\
\text { 4) Lack of real-time carbon emissions regulation. }\end{array}$ \\
\hline
\end{tabular}

At the regional level, the country's emissionsreduction target is progressively assigned to eachregion and institution. Thus, with the use of PIDcontrol, the government will be able to regulatecarbon emissions of this area in real time. Throughreal-time control of the highest value of carbonemission, the total cycle carbon emission, and theratio between carbon sources and carbon sinks,precise regulation of carbon emissions can beachieved. Inaddition, through monitoring thechanges in the concentration of $\mathrm{CO} 2$, researchinstitutions could analyze the 
circulating mechanismof $\mathrm{CO} 2$, and the relationship between carbon sourcesand carbon sinks, which as a whole provide atheoretical basis for the realization of carbon balancein urban planning(Osman et al., 2016). At the corporate level, with thePID control, enterprise automation system can alsoregulate the actual carbon emissions in either static ordynamic way. And then according to carbonemissions requirements, utilization of energy andproduction mode can be automatic adjusted toachieve better production results. It should be noted that the intelligent carbonemission governance platform need to get feedbackfrom the actual construction in time, so as to makeevaluations and amendments to the previousdecisions (Fig. 1, Table 3).

\subsection{Smart Energy Governance}

To achieve the expected energy consuming targets,the measures such as energy conservation governance,energy consumption metering must be used in theprocess of energy governance. Firstly, urban energyinformation must be collected by the technologiessuch as the Internet of things, RFID, which includethe spatial element information of energy stations, energy reserves information, energy transmission anddistribution network information, energy use statusinformation, etc. Then, put the information listedabove into smart energy information governanceplatform.

Table 4 Energy governance goals and issues

\begin{tabular}{|c|c|c|}
\hline \multicolumn{2}{|r|}{ Goal and task } & Main issues \\
\hline Goal: & $\begin{array}{l}\text { - Save energy and achieve the expected } \\
\text { energy consumption }\end{array}$ & 1) Hysteresis of energy deployment information \\
\hline Task: & $\begin{array}{l}\text { 1) Select the type of energy } \\
\text { 2) Develop energy deployment program } \\
\text { 3) Energy use management } \\
\text { 4) Energy consumption measurement } \\
\text { 5) Energy performance evaluation }\end{array}$ & $\begin{array}{l}\text { its fluctuation } \\
\text { 3) Lack of awareness of energy conservation } \\
\text { 4) Energy consumption measurement inaccuracies }\end{array}$ \\
\hline
\end{tabular}

After recognizing, analyzing, and a seriescomplex processing to the essential information, theresult can be shared to public information platform. Relative department such as government governancesystem, enterprise automation system, transformationof scientific research achievements and public servicesystem each takes what he needs and take advantageof the data. Next, according to selected information,these departments can make the originaldecision anadaptive correction and formulate important decisionof low carbon energy system, such as guide tochoose the energy station location, formulate the energyfacilities planning, deploy the 
energy supply, updateenergy system, and optimize the energy ratio. At last,the construction information can be feedback in timeaccording to the practical problems in the planningand construction. The decision's accuracy andcorrectness can be ensured through the secondaryamendment by low carbon information governanceplatform (Fig. 1, Table 4).

\subsection{Smart Traffic Governance}

In the process of traffic governance, the methodssuch as engineering technology, legal system andeducation can be used to make traffic as secure,unobstructed, lower pollution, lower energyconsumption as possible(Osman et al., 2016). Firstly, the information oftraffic flow, road facilities states, parking place, andpublic transport usage obtained by induction deviceand remote sensing device must be input into thesmart traffic governance platform. After classified,filtered, processed and calculated by the platform, theresult may be shared by the departments ofgovernment governance system, transformation ofscientific research achievements and public servicesystem. Then, according to vehicles travel situation indifferent road sections at different times, the relativedepartments of government can guide and dredgetraffic rapidly and effectively. Meanwhile, roadfacilities can be maintained and updated in time. Notenvironmental friendly mode of transport can bepointed out, warned or punished by means ofpersonal information terminal such as cellphone, IPad,vehicle mounted device.

Table 5 Traffic governance goals and issues

\begin{tabular}{|c|c|c|}
\hline & Goal and task & Main issues \\
\hline Goal: & $\begin{array}{l}\text { - Make transportation safer, smoother, less } \\
\text { pollution and less energy consumption }\end{array}$ & 1) Traffic information isn't comprehensive or \\
\hline Task: & $\begin{array}{l}\text { 1) Reduce traffic congestion } \\
\text { 2) Road, parking fee management } \\
\text { 3) maintain of road safety } \\
\text { 4) Security of public transport development }\end{array}$ & $\begin{array}{l}\text { 2) Limited road sudden emergency handling } \\
\text { capability } \\
\text { 4) The continued expansion of the number of } \\
\text { 4) Public support for public transportation is not }\end{array}$ \\
\hline
\end{tabular}

Through study existingtraffic problems, scientific research organizationprovide a theoretic support to improve trafficproblems. Because the public can know roadconditions and obtain parking information at realtime by personal information terminal, the roadresource can be used more reasonable and the trafficcongestion condition can be relieved. Simultaneously,traffic 
participants may help the optimal systemdecision-making made by means of the mechanism offeedback to report the problem information to smart traffic information governance platform in time (Fig.1, Table 5).

\subsection{Smart Building Governance}

In building governance, the renewable energy andresource can be circulating used to reduce the harm tonature ecological environment throughout the processof building (Salem et al., 2016). The obtained information such asbuilding material and all kind of energy consumingcan be input to the platform of smart buildinggovernance. After a series data analysis, calculationand decision-making, the result can be used to guideenergy consume estimating in the unit of department. By means of energy consuming data, the retrofit scheme about original building and equipment system may be formed. As a result, the building energy efficiency can be promoted unceasingly, and the residents are advocated a better lifestyle (Fig. 1, Table 6).

Table 6Building governance goals and issues

\begin{tabular}{|c|c|c|}
\hline \multicolumn{2}{|r|}{ Goal and task } & Main issues \\
\hline Goal: & $\begin{array}{l}\text { - Reduce construction damage to the natural } \\
\text { environment. }\end{array}$ & 1) Construction process produces a large number of \\
\hline Task: & $\begin{array}{l}\text { 1) Promote new materials } \\
\text { 2) Construction equipment maintenance } \\
\text { 3) Reduce the pollution during the building } \\
\text { energy consumption } \\
\text { 4) Lead the low-carbon and eco-friendly lifestyle }\end{array}$ & $\begin{array}{l}\text { 2) Limited building sudden emergency handling } \\
\text { capability } \\
\text { 3) Building energy information isn't timely and } \\
\text { accurate enough } \\
\text { 4) Public awareness of low-carbon lifestyle is not } \\
\text { strong }\end{array}$ \\
\hline
\end{tabular}

\section{Conclusion}

The integration of Smart City and Low-carbon City isthe direction of modern city development. TheLow-carbon City supported by smart techniques isthe inevitable choice to realize more highleveldevelopment for itself. The research of Smart Cityand Low-Carbon city has just started in developing countries. Howto integrate the two aspects is still a new topic. Basedon the deep study on the techniques of smart city andlow-carbon information governance, this paper haveproposed an approach to construct urban low-carboninformation governance system under the backgroundof Smart City in developing countries. The constructing principles andimplement path are discussed yet. At the angle ofwhole process from information acquisition toend-user 
aspect, how to perform low-carboninformation governance with smarttechniques isexpounded. This proposal will be expected to speedup the implement of city low-carbon governance, andprovide a decision making basis for formulatingcarbon emission reduction measures and making outlow-carbon planning method.

\section{References}

- BaoxingQIU (2009). The transformation trends ofurban development model in chinalowcarbon eco-city. Urban Studies. 8, 1-6.

- Chaolin GU (2011). Transitional development andfuture urban forms. City Planning Review. 11,23-34.

- Osman, T., Divigalpitiya, P. \&Arima, T., 2016. Driving factors of urban sprawl in Giza Governorate of Greater Cairo Metropolitan Region using AHP method. Land Use Policy, 58, pp.21-31. doi:10.1016/j.landusepol.2016.07.013.

- Osman, T.; Divigalpitiya, P.; Osman, M.M.; Kenawy, E.; Salem, M.; Hamdy, O. Quantifying the Relationship between the Built Environment Attributes and Urban Sustainability Potentials for Housing Areas. Buildings 2016, 6, 39.doi:10.3390/buildings6030039.

- Osman, T., Divigalpitiya, P., \& Osman, M. M., The impact of Built Environment Characteristics on Metropolitans Energy Consumption: an Example of Greater Cairo Metropolitan Region. Buildings, 2016 6(2), 12; doi:10.3390/buildings6020012.

- Osman, T.; Divigalpitiya, P.; Arima, T., Effect of Urban Development Patterns on TrafficRelated $\mathrm{CO}_{2}$ Emissions in Greater Cairo Metropolitan Region. 都市 - 建築学研究 :九州大学大学院人間環境学研究院紀要.. (29):2016.1. 29-38 ISSN 1346-5325.

- Qi LI, Huan-fa CHEN, Ling-yanJIN, \&ShuaiLIU (2014). Urban and regional carbon accountingmodel for carbon management of Smart City.Science of Surveying and Mapping. 8.

- Rongtao DING (2011). The research on constructionand development of low-carbon eco-city'sinformation administration system. UrbanStudies. 9, 95-99.

- Salem, M., Osman, T., 2016.A new map for urban development in Egypt, depending on mega projects of renewable energy. Proceedings of the 2016 International conference of sustainable mega projects,British University in Egypt, pp. 9-18.

- Sidong ZHAO, Dong OUYANG, \& Yuan ZHONG(2013). Intelligent city planning's effect to urbanplanning. Planners. 2, 5-10 
- Tianhang HUANG, Ruilin LIU, \&Anrong DANG(2011). The development of Smart City andlow-carbon economy. Beijing Planning Review.2, 39-44.

- Xibo WU, \&Zaigao YANG (2010). The concept ofsmart city and future city development. UrbanStudies. 11, 56-60.

- Xin HE, \& Yao XIE (2011). Measurement of foreignenvironmental management and its Implicationsfor China. Macroeconomics. 9, 105-111.

- Yi LIU, Dongxu YANG, \&Zhaonan CAI (2013). Aretrieval algorithm for TanSatXCO2observation: Retrieval experiments usingGOSAT data. Chin Sci Bull. 58, 1520-1523.

- Zhilin LIU, \& Bo QIN (2013). Urban form andlow-carbon cities: research progress andplanning strategies. Urban PlanningInternational. 2, 4-11. 